\title{
ALTERNATIF PIDANA BERSYARAT BAGI KORUPTOR DALAM PERSPEKTIF KEKUASAAN KEHAKIMAN (KAJIAN PUTUSAN NO 675. K/Pid.Sus./2010)
}

\author{
Slamet Riyady \\ Dosen Fakultas Hukum, Universitas Pamulang \\ E-mail: Sangamet2810@gmail.com
}

Received: - /Revised: - /Accepted: Ags 2018

\begin{abstract}
Alternatif pidana bersyarat bagi koruptor dianggap belum sesuai dengan undang - undang namun Hakim mempunyai kebebasan untuk memilih jenis pidana dan pemidanaan yang sesuai dengan kehendaknya karena pada asas hukum positif pidana diindonesia menggunkan sistem alternatif pencantuman sanksi pidana, disamping dianutnya sistem pidana minimum, maksimal umum dan juga maksimal khusus yang ada dalam masing - masing tindak pidana.
\end{abstract}

Kata kunci : Alternatif Pidana bersyarat dalam kekuasaan kehakiman

\section{ABSTRACT}

Criminal conditional alternatives to corruptors are deemed to be inconsistens with the law but judges have the freedom to choose the types of criminal and criminal punishment in accordance with their will because the positive criminal law principle of Indonesia uses an alternative system of inclusion of criminal sanctions, in addition to the adoption of a minimum, maximally public penal system, and as well as the specific maximum available within each of the offenses.

Keyword : aconditional criminal alternative in the judical powers

\section{PENDAHULUAN}

Pemberantasan korupsi pada dewasa ini sedang giat-giatnya dicanangkan oleh Pemerintah yang diwakili oleh KPK (Komisi Pemberantasan Korupsi), dalam mengungkapkan pelaku yang diduga melakukan tindak pidana korupsi, baik dikalangan eksekutif, yudikatif maupun para politisi. Tren perilaku korupsi 
tampak semakin endemis yang merambah dalam segala aspek kehidupan masyarakata, seakan- akan telah membudaya dan berkembang di negara Indonesia.

Korupsi merupakan perbuatan yang merugikan keuangan negara. ${ }^{1}$. dimana keuangan negera diatur dalam anggaran pendapatan belanja negara ( $\mathrm{APBN}$ ) yang mana semua anggaran keuangan dalam APBN sudah dibagi keseluruh Lembaga Kementerian, Pemerintah Provinsi, Kabupaten / Walikota, dan Badan Usaha Milik Negara. Adapun kata korupsi itu sendiri berasal dari bahasa latin corruptio atau corruptus ${ }^{2}$ secara harfiah dari kata itu adalah kebusukan, keburukan, kebejatan, ketidakjujuran, dapat disuap, tidak bermoral, penyimpangan dari kesucian. Sekarang di Indonesia sendiri ketika orang berbicara korupsi maka yang terbayang adalah hanya perbuatan jahat yang menyangkut keuangan negara dan suap, padahal pendekatan yang dilakukan masalah korupsi beragam seperti "nepotisme" yang klasifikanya adalah keluarga atau teman pada posisi pemerintahan tanpa memenuhi persyaratan untuk itu. yang tentunya hal seperti ini sukar dicari normanya dalam hukum pidana.

Sesuai dengan perkembangan pengetahuan dan budaya masyarakat korupsi juga ikut tumbuh sedemikan rupa sehingga memiliki bentuk dan jenis yang sangat beragam, Prof Amien Rais mengatakan sedikitnya ada empat macam jenis korupsi diantaranya :

\footnotetext{
${ }^{1}$ Pengertian atau maksud keuangan negara dan perekonomian negara pasal 2 UU No 31 Tahun 1999, dimana dalam penjelasan umum yang dimaksud keuangan negara adalah seluruh kekayaan negara dalam bentuk apapun,baik yang dipisahkan ataupun yang tidak dipishkan.

2 Kamus Hukum, Fockema Andrea, Bandung : Bina Cipta,1983 . Huruf C Terjemahan Bina Cipta.
} 
1. Korupsi ekstortif yaitu sogokan atau suap yang dilakukan oleh pengusaha kepada penguasa, misalnya untuk mendapatkan hak penguasaan hutan atau fasilitas tertentu, seorang menggunakan uang untuk menyogok pejabat yang berwenang

2. Korupsi manipulatife yaitu seoarang yang memilki kepentingan ekonomis meminta kepada eksekutif ataupun legislative untuk membuat peraturan atau undang-undang yang menguntungkan bagi usaha ekonominya, sekalipun berdampak negatif bagi masyrakat banyak

3. Korupsi nepotisme yaitu korupsi yang terjadi karena adanya ikatan keluarga, misalnya seseorang yang selalu mementingkan isteri, anak, menantu, keponakan untuk mendapatk pasilitas yang berlebihan yang tidak masuk akal.

4. Korupsi subversif, dimana mereka merampok kekayaan negara secara sewenang-wenang untuk dialihkan kepada pihak asing, tentu dengan sejumlah keuntungan pribadi, misalnya penambangan pihak asing yang kongkalikong dengan pejabat tertentu dengan pembagian yang tidak wajar seperti dalam kasus freeport. ${ }^{3}$

Di tinjau dari Persepektif yuridis tindak pidana korupsi merupakan kejahatan yang luar biasa ( Extra Ordinary Crimes), yang mana bila kita lihat dari sisi akibat dampak negatif yang sangat merusak tantanan kehidupan bangsa Indonesia merupakan perampasan hak ekonomi dan hak sosial rakyat Indonesia. ${ }^{4}$ Oleh sebab itulah di perlukannya Pemidanaan yang dapat menimbulkan Efek jera bagi koruptor dan bagi masyarakat.

\footnotetext{
3 Alfitra,Modus Operandi Pidana Khusus Diluar KUHP,Jakarta,RaihAsas Sukses, 2014,hlm,10.

4 Lilik Mulyadi, Pembalikan Beban Tindak Pidana Korupsi,PT Alumni, Jakarta Cetakan Ke - 1 Tahun 2007, hlm, 17.
} 
Adapun fungsi pemidanaan di Indonesia adalah menjaga keseimbangan individu dengan kepentingan masyarakat dalam mencapai kesejahteraan bersama, yang mana semua aturan perundang - undangan mengenai hukum pidana subtantif hukum pidana formil dan hukum pelaksanaan pidana dapat dilihat sebagai satu kesatuan sebagai sistem pemidanaan yang mana beberapa ahli berpendapat untuk menakut-nakuti orang jangan sampai melakukan kejahatan, baik secara menakut-nakuti orang banyak (generale preventive) maupun dengan cara menakut-nakuti orang tertentu yang sudah menjalankan kejahatan agar dikemudian hari tidak melakukan kejahatan lagi (special preventive $)^{5}$ dan untuk mendidik atau memperbaiki orang-orang yang sudah menandakan suka melakukan kejahatan agar menjadi orang yang tabiatnya, sehingga bermanfaat bagi masyarakat.

Negara sebagai penguasa dalam penegakan hukum yang berhak menjatuhkan sanksi pidana dan hanya satu - satunya subjek hukum yang mempunyai hak menghukum ( Ius Punindi). Kewenangan negara memberikan sanksi pidana didelegasikan kepada penegak hukum yang bekerja dalam satu sistem yang terpadu (Integrated Criminal Justice System)6, dalam tahap ini proses penyelesaian perkara pidana melalui tahap tertentu yang setiap tahapannya dipegang oleh pejabat atau petugas yang berbeda namun masing - masing mendukung dalam proses penyelesaian perkara pidana.

Salah satu sub penting atau pendukung yang mempunyai peranan sangat penting dalam menegakan hukum terutama

${ }^{6}$ Alfitra, Gugur Atau Batalnya Hak Penuntutan Serta Menjalankan Pidana Menurut Hukum Positif Indonesia, Sejahtera Printing, Jakarta, 2010,hlm,1. 
pelaksanaan sistem peradilan pidana adalah pengadilan, karena pengadilan sebagai benteng terakhir dalam mencari keadilan, yang mana di dalamnya terdapat para hakim diberikan oleh undang - undang untuk mengadili, kata mengadili itu sendiri adalah suatu pergualatan kemanusiaan untuk mewujudkan hukum, oleh karenanya mengadili tanpa adanya suatu hubungan yang bersifat manusia anatara hakim dan terdakwa kerapkali dirasakan sebagai memperlakukan ketidakadilan ${ }^{7}$

Hakim mempunyai kebebasan untuk memilih jenis pidana dan pemidanaan yang sesuai dengan kehendaknya karena pada asas hukum positif pidana diindonesia menggunkan sistem alternatife pencantuman sanksi pidana, disamping dianutnya sistem pidana minimum, maksimal umum dan juga maksimal khusus yang ada dalam masing - masing tindak pidana. Hakimlah yang pada dasarnya menentukan putusan suatu perkara yang berdasarkan itergritas, intelektual, dan moral terhadap nilai nilai keadilan, dalam Pasal 1 butir 8 KUHAP menyebutkan bahwa " Hakim adalah pejabat peradilan negara yang diberi wewenang oleh Undang - Undang untuk mengadili”

Hakim juga diberikan kekusaan yang merdeka, sebagaimana penjelasan pasal 24 dan 25 Undang - Undang Dasar Republik Indonesia Tahun 1945 yaitu bahwa "kekuasaan kehakiman merupakan kekuasaan yang merdeka untuk menyelenggarakan peradilan guna mengekan hukum dan keadilan,syarat- syarat untuk menjadi hakim ditetapkan dengan undang - undang"

Kata kebebasan hakim tidak diberikan penjelasan lebih rinci dan lebih teknis oleh perundang - undangan yang memaknai

\footnotetext{
${ }^{7}$ Roeslan Saleh, Mengadili Sebagai Pergulatan Kemanusiaan, Aksara Baru, Jakarta, 1979, hlm,1 22.
} 
bahwa kebebasan kehakiman harus berada dalam kerangka prinsip kemandirian, hakim adalah bagian subtansi dari lembaga peradilan sebagai pejabat yang melaksanakan kekuasaan kehakiman, sebagaimana pasal 3 undang - undang No 48 Tahun 2009 yang menyatakan bahwa dalam menjalankan tugas dan fungsinya hakim wajib menjaga kemandirian peradilan.

Menurut Oemar Seno Adji “ suatu pengadilan yang bebas dan tidak dipengharuhi merupakan syarat yang indispensable sebagai negara hukum, kebebasan berarti tidak ada campur tangan atau turun tangan dari kekuasaan eksekutif dan legislatif dalam menajalankan Funsi peradilan 8

Pasal 24 ayat 1 Undang- Undang Dasar 1945 kekuasaan kehakiman adalah kekuasaan kehakiman yang merdeka untuk menyelenggarakan peradilan guna menegakkan hukum dan keadilan”. Sedangkan, UU Kekuasaan Kehakiman mengharuskan hakim menggali nilai-nilai yang hidup dalam masyarakat. Pasal 27 ayat (1) UU No. 14 Tahun 1970 menyebutkan 'hakim sebagai penegak hukum dan keadilan wajib mengali, mengikuti, dan memahami nilai-nilai hukum yang hidup dalam masyarakat'. Rumusan ini tidak mengalami perubahan dalam UU No. 35 Tahun 1999 yang mana telah dirubah Undang - Undang 48 Tahun 2009 dalam Pasal 5 ayat 1 Undang - Undang menegasakan " Hakim dan Hakim konstitusi wajib menggali mengikuti dan memahami nilai - nilai hukum dan rasa keadilan di dalam masyarakat

Sedangkan fungsi kekuasaan kehakiman di atur dalam pasal 1 Undang - Undang No 48 tahun 2009 yang berbunyi "kekuasaan kehakiman adalah kekuasaan negara yang merdeka untuk

\footnotetext{
${ }^{8}$ Oemar Seno Adji, Peradilan Bebas Negara Hukum, Erlangga ,Jakarta 1987,hlm, 46
} 
menyelenggarakan peradilan guna menegakan hukum dan keadailan berdasarkan Pancasila demin terselenggaranya negara hukum Republik Indonesia" Setelah hakim mempunyai kekuasan untuk memutus suatu perkara atau memvonis tapi tidak jarang terkadang putusan hakim kurang mencerminkan keadilan terhadap para pelaku kejahatan dan tidak menimbulkan efek jera di dalam masyarakat, contohnya saja pada saat ini dalam tindak pidana korupsi yang tidak jarang kita dengar seseorang secara terbukti melakukan tidak pidana korupsi, namun terpidana atau orang tersebut tidak perlu menjalankan pidana badannya dalam penjara, yang mana lebih dikenal dalam hukum postif adalah pidana bersyarat ( voorwaardelijke veroordeling).

Penjatuhan pidana bersyarat dalam tindak pidana korupsi dianggap mencederai dan bertentangan dengan semangat pemerintah dalam upaya pemberantasan tindak pidana korupsi salah satu sumber tulisan ini adalah Putusan No 675. K/Pid.Sus./2010 Sesuai Amar Putusan Hakim Mahkamah Agung tersebut terdakwa Cik Umar S.H, menyatakan terdakwa terbukti secara sah dan meyakinkan bersalah melakukan tindak pidana membujuk untuk melakukan korupsi, menjatuhkan pidana kepada terdakwa oleh karena itu dengan dipidana penjara selama 1(satu) tahun dan pidana denda sebesar Rp50.000.000,- (lima puluh juta rupiah), dengan ketentuan apabila pidana denda tidak dibayar, maka kepad terdakwa dikenakan hukuman pengganti berupa pidana kurungan selama 1 (satu) bulan, memerintahkan pidana tersebut di perlu dijalani kecuali apabila kemudian hari dalam putusan hakim diberikan perintah lain atas alasan bahwa terdakwa sebelum masa percobaan selama 2 (dua) tahun berakhir telah bersalah menetapkan tindak pidana. 
Apabila kita cermati bentuk putusan di atas tersebut seharusnya terpidana menjalani kurungan badan berupa penjara selama satu tahun tetapi hakim berpendapat pidana tersebut tidak perlu dijalani kecauali perintah lain atas alasan terdakwa sebelum masa percobaan dua tahun berakhir telah bersalah, yang berarti dalam pemidaan hukum pidana kita sering disebut pidana bersyarat. Sedangkan di dalam undang - undang pemberantasan korupsi telah mengatur batas ancaman pidana miniumum khusus, pidana denda yang lebih tinggi, dan ancaman pidana mati yang merupakan ancaman pemberatan dalam undang - undang pemberantasan tindak pidana korupsi.

Lebih jelasnya di atur dalam Pasal 2 dan Pasal 3 UU RI No. 31 Tahun 1999 tentang Pemberantasan Tindak Pidana Korupsi jo. UU RI No. 20 Tahun 2001 tentang Perubahan Atas UU RI No. 31 Tahun 1999 tentang Pemberantasan Tindak Pidana Korupsi, tindakan yang tergolong sebagai tindak pidana korupsi adalah:

1. Kerugian keuangan negara, terdapat dalam :

a) Pasal 2 UU RI No. 31 Tahun 1999, menyatakan bahwa:

1) Setiap orang yang secara melawan hukum melakukan perbuatan memperkaya diri sendiri atau orang lain atau suatu korporasi yang dapat merugikan keuangan negara atau perekonomian negara, dipidana dengan pidana penjara seumur hidup atau pidana penjara paling singkat 4 (empat) tahun dan paling lama 20 (dua puluh) tahun dan denda paling sedikit Rp. 200.000.000,00 (dua ratus juta rupiah) dan paling banyak Rp. 1000.000.000,00 (satu milyar rupiah). 
2) Dalam hal tindak pidana korupsi sebagaimana dimaksud dalam ayat (1) dilakukan dalam keadaan tertentu, pidana mati dapat dijatuhkan.

b) Pasal 3 UU RI No. 31 Tahun 1999, menyatakan bahwa :

Setiap orang yang dengan tujuan menguntungkan diri sendiri atau orang lain atau suatu korporasi, menyalahgunakan kewenangan, kesempatan atau sarana yang ada padanya karena jabatan atau kedudukan yang dapat merugikan keuangan negara atau perekonomian negara, dipidana dengan pidana penjara seumur hidup atau pidana penjara paling singkat 1 (satu) tahun dan paling lama 20 (dua puluh) tahun dan atau denda paling sedikit Rp. 50.000.000,00 (lima puluh juta rupiah) dan paling banyak Rp. 1.000.000.000,00 (satu milyar rupiah).

Kata - kata pidana bersyarat atau pemidanaan bersyarat adalaah sekedar suatu istilah umum, sedangkan yang dimaksud bukanlah tentang pemidanaannya yang bersyarat, melainkan pelaksanaan pidana itu yang digantungkan pada syarat- syarat tertentu ${ }^{9}$. Artinya kendati suatu pidana telah dijatuhkan kepada pelaku/ terpidana namun pidana belum / menjalani sepanjang terpidana tidak melanggar syarat- syarat yang diwajibkan kepadanya ketika putusan itu diterima, jika dilihat dari sudut istilah adalah lebih tepat jika disebut sebagai pelaksanaan pidana yang dipersyaratkan.

Sedangkan Pasal 4 UUTipikor yang menyatakan bahwa pengembalian kerugian keuangan negara atau perekonomian negara tidak menghapuskan dipidananya pelaku tindak pidana

${ }^{9}$ E.Y.Kanter, Asas- Asas Hukum Pidana Di Indonesia Dan Penerapannya,Jakarta, Storia Grafika,hlm,. 473 
sebagaai mana dimaksud Pasal 2 dan 3, penjelasan pasal ini menyebutkan bahwa pengembalian kerugian negara atau perekonomian negara hanya merupakan salah satu faktor yang meringankan saja.

\section{PERMASALAHAN}

Berdasarkan latar belakang yang telah diuraiakan penulis tersebut terdapat pokok permasalahan dalam tulisan ini adalah pertama, apakah pertimbangan hakim dalam menjatuhkan alternatife pidana bersyarat terhadap koruptor ?, kedua apakah pidana bersyarat bagi koruptor sebagai pencegahan tindak pidana korupsi?

\section{METODE PENELITIAN}

Penulisan ini menggunkan metode yuridis normatif, yaitu penelitian terhadap norma-norma hukum pidana yang terdapat dalam peraturan perundang - undangan pidana Indonesia, dengan menggunakan metode deskritif analisis, data yang digunakan Primer adalah Putusan No.675K/Pid.Sus/2010, data sekunder publikasi hukum seperti buku, hasil karya ilmiah, artikel dan internet.

\section{PEMBAHASAN}

\section{Pidana dan Pemidanaan di Indonesia.}

Istilah penghukuman berasal dari kata "straf"sedangkan istilah dihukum berasal dari kata "wordt gestraf" yang artinya pidana dan diancam dengan hukuman ${ }^{10}$. Istilah ini inkonvesional dan menyimpang dari kebiasaan yang biasanya peristilahan hukum pidana "strafrecht" yang sudah menjadi pasangan dari hukum perdaata civilrecht dan Kitab Undang - Undang Hukum

\footnotetext{
${ }^{10}$ Juhaya S Praja ,Teori Hukum Dan Aplikasinya, Bandung : Pustaka Setia, Cetakan Kedua 2014, hlm,187.
} 
Pidana "wetboek van strefrecht" sudah umum bagi mereka yang menggunakan hukum dan dihukum.

Sudarto mengatakan " bahwa penghukuman berasal dari kata dasar hukum atau memutuskan hukumnnya, menetapkan hukum untuk suatu peristiwa tidak hanya menyangkut bidang hukum pidana saja, tetapi bidang juga hukum perdata. Selanjutnya dia depinisikan yang artinya menjadi penghukuman dalam perkara tindak pidana yang sinonim dengan pemidanaan atau pemberian / penjantuhan hukuman oleh hakim, penghukuman dalam arti demikian mempunyai makna sama dengan sentence atau veroldeling missal-nya dalam pengertian sentence conditionally atau voorwardelijk verodeel yang sama artinya dengan dihukum bersyarat atau dipidana bersyarat ${ }^{11}$

Jenis - jenis pidana menurut Pasal 10 KUHP dibedakan lima pidana pokok dan tiga pidana tambahan, yaitu:

a. Pidana pokok terdiri dari :

1) Pidana mati

2) Pidana penjara

3) Pidana kurungan

4) Pidana denda

5) Pidana tutupan (berdasarkan Undang-Und ang RI No. 20 tahun 1946)

b. Pidana tambahan terdiri dari:

1) Pencabutan hak - hak tertentu

2) Perampasan barang - barang tertentu dan,

3) Pengumuman Putusan hakim

${ }^{11}$ Ibid , hlm, 188. 
Adapun teori - teori pemidanaan dapat dibagi menjadi tiga teori yaitu:

1. Teori absolute memandang bahwa pemidanaan merupakan pembalasan atas kesalahan yang telah dilakukan sehingga berorientasi pada pada perbuatan dan terjadinya kejahatan itu.dalam artian teori ini mengedepankan bahwa sanski dalam hukum pidana dijatuhkan semata- mata karena seseorang telah melakukan suatu kejahatan sebagai akibat mutlak yang harus ada sebagai pembalasan kepada orang yang melakukan kejahatan.

2. Teori teletologis (tujuan) memandang bahwa pemidanaan bukan sebagai pembalasanpembalasan atas kesalahan pelaku,melainkan sarana mencapai tujuan yang bermanfaat untuk melindungi masyarakat menuju kesejahteraan

3. Teori retributif- teleologis memandang bahwa tujuan pemidanaan bersifat plural. Teori ini menggabungkan antara prinsif- prinsif tujuan dan retributif sebagai satu kesatuan, yang mana dalam teori ini bercorak ganda, yaitu pemidanaan mengandung karakter retributif sejauh pemidanaan dilihat suatu keritik moral dalam menjawab tindakan yang salah. Adapun karakter teologisnya terletak pada bahw tujuan kritik moral tersebut merupakan reformasi atau perubahan perilaku terpidana pada kemudian hari. Panadangan teori ini menganjurkan adanya kemungkinan menhadakan artikulasi terhadap pemidanaan yang mengintegrasikan beberapa fungsi sekaligus retributif bersifat utilatirian yaitu pencegahan 
dan rehabilitasi sebagai sasaran yang harus dicapai oleh rencana pemidanaan. Karena tujuannya bersifat intergratif, perangkat tujuan pemidanaan adalah: (a) pencegahan umum dan khusus,(b) perlindungan masyarakat, (c) memelihara solidaritas masyarakat, (d) pengimbalan / pengimbangan dan mengenai tujuan, titik beratnya bersifat kasus itu

Sedangkan pemidanaan di Indoneisa itu menurut L.H.C. Hullsman adalah aturan perundang-undangan yang berhubungan dengan sanksi dan pemidanaan (the statutory rules relating to penal sanction and punishment) ${ }^{12}$.

Dari pendapat di atas bahwa pemidanaan mencakup keseluruhan ketentuan perundang-undangan yang mengatur bagaimana hukum pidana itu ditegakkan atau dioperasionalkan secara konkret sehingga seseorang dijatuhi sanksi (hukum pidana). Ini berarti semua aturan perundang-undangan mengenai Hukum Pidana Substantif, Hukum Pidana Formal dan Hukum Pelaksanaan Pidana dapat dilihat sebagai satu kesatuan sistem pemidanaan.

Apabila ketentuan pidana yang tercantum dalam semua Undang-Undang Khusus di luar KUHP merupakan bagian khusus (sub sistem) dari keseluruhan sistem pemidanaan dengan demikian, sistem pemidanaan dalam Undang-Undang Khusus di luar KUHP harus terintegrasi dalam (konsisten dengan) aturan umum (general rules). Namun, dalam Undang-Undang Khusus di luar KUHP tersebut dapat membuat aturan khusus yang menyimpang atau berbeda dengan aturan umum.

${ }^{12}$ Barda Nawawi Arief, Bunga Rampai Kebijakan Hukum Pidana, Citra Aditya Bakti, Bandung, 2002,hlm, 129. 
Dari uaraian pemidanaan secara garis besar mencakup 3 (tiga) permasalahan pokok, yaitu Jenis pidana (strafsoort), lamanya ancaman pidana (strafmaat), dan pelaksanaan pidana (strafmodus) dengan penjelasannya :

a) Jenis pidana (strafsoort) Jenis pidana dapat dilihat dalam ketentuan Pasal 10 KUHP yang terdiri,

1) Pidana pokok berupa :

- Pidana mati ;

- Pidana penjara;

- Pidana kurungan;

- Pidana denda ;

- Pidana tutupan.

2) Pidana tambahan berupa :

- Pencabutan beberapa hak tertentu ;

- Perampasan barang-barang tertentu ;

- Pengumuman putusan hakim. Dengan demikian, sesuai dengan ketentuan Pasal 10 KUHP, Indonesia hanya mengenal pidana pokok dan pidana tambahan.

b) Lamanya Ancaman Pidana (strafmaat), beberapa pidana pokok yang seringkali secara alternatif diancamkan pada perbuatan pidana yang sama. hakim hanya dapat menjatuhkan satu diantara pidana yang diancamkan itu bahwa hakim bebas dalam memilih ancaman pidana tergantung dari keadaan yang memberatkan atau meringankan seperti pasal Pasal 53 ayat (2) dan Pasal 57 . KUHP

c) Pelaksanaan Pidana (strafmodus), KUHP yang berlaku di Indonesia pada saat ini belum mengenal hal yang 
dinamakan pedoman pemidanaan. Oleh karena itu, hakim dalam memutus suatu perkara diberi kebebasan memilih jenis pidana (strafsoort) yang dikehendaki, sehubungan dengan sistem alternatif dalam pengancaman di dalam undang-undang ini disebabkan undang-undang hanya menentukan batas maksimum dan minimum pidananya saja. Sebagai konsekuensi dari masalah tersebut, akan terjadi hal yang disebut dengan disparitas pidana.

\section{Alternatife Pidana Bersyarat Koruptor Bertentangan Dengan Undang - Undang Pemberantasan Tindak Pidana Korups}

Pidana bersyarat adalah merupakan perintah dari hakim, bahwa pidana yang diputuskan atau ndijatuhkan tidak akan dijalani terpidana, kecuali kemudian hakim memerintahkan supaya dijalani karena terpidana;

a. Sebelum habis masa percobaan melanggar syaratb umum,yaitu melakukan suatu tindak pidana atau

b. Dalam masa percobaan tersebut, melanggar suatu syarat khusus (jika diadakan) atau Dalam masa yang lebih pendek dari percobaan tersebut, tidak melaksanakan syarat yang lebih khusus, berupa kewajiban mengganti kerugian pihak korban sebagi akibat dari tindakan terpidana. ( pasal $14 \mathrm{c}$ KUHP) 13

Penjatuhan pidana bersyarat dalam tindak pidana korupsi banyak menuai kntroversi dalam masyarakat, karena masyarakat umum sebagian menilai hukuman pidana bersyarat atau

\footnotetext{
${ }^{13}$ Ibid , hlm,473.
} 
penghukuman percobaan sama halnya dengan pembebasan terhadap para koruptor yang beranggapan para koruptor tidak menjalani hukuman di dalam lembaga pemasyarakatan, karena bertentangan dengan UUPTPK yang telah sendiri mengatur ancaman yang ditentukan buat para koruptor

Penjatuhan pidana percobaan terhadap terpidana korupsi akan mengurangi kesan beratnya tipikor sehingga menyebabkan orang tidak lagi melihat ancaman pidana dalam Undang-undang Tipikor sebagai sesuatu yang menakutkan. Dalam hal ini pemidanaan tipikor telah kehilangan fungsi pencegahan umumnya. Pencegahan khusus berupa efek jera yang diharapkan muncul dari pemidanaan korupsi pun juga dikhawatirkan hilang bersamaan dengan penerapan pidana, dengan adanya Pasal 4 dalam Undang-udang Tipikor yang telah menyatakan pengembalian kerugian negara tidak menghapus dipidannya seseorang, hanya sekedar mengurangi hukuman dan dalam hal ini bukan berarti diberikan pidana percobaan.

Pasal 11 berbunyi “ dipidana penjara paling singkat 1 (satu) tahun dan paling lama 5 ( lima) tahun dan atau pidana denda paling sedikit Rp50.000.000,00 ( lima puluh juta rupiah) dan Paling banyak Rp 250.000.000,00 ( dua ratus lima puluh juta rupiah ) pegawai negeri atau penyelenggara negara yang menerima hadiah atau janji padahal diketahui patut diduga, bahwa hadiah atau janji tersebut diberikan karena kekuasaan atau kewenangan yang berhubungan dengan jabatannya, atau yang menurut pikiran orang yang memberikan hadiah atau janji disebut ada hubungan dengan jabatannya.

Sedangkan pasal 18 ayat (2) hanya mengatur tentang tata cara uang pengganti apabila tidak terbayarkan yang berbeda 
dengan ayat (3) yang bersifat mewajibkan untuk adanya pidana penjara sebagai pengganti dari uang yang tidak terbayarkan berdasarkan putusan hakim, yaitu dengan kalimat "maka dipidana dengan pidana penjara yang lamanya tidak melebihi ancaman maksimum dari pidana pokoknya" Selain itu jika suatu pemidanaan yang dikenakan pasal yang pada unsurnya mengandung kerugian negara, maka wajib ditambahkan dengan pasal 18 ayat (3) tersebut, sebagaimana pasal 2 dan 3 UUPTPK, selebihnya pasal yang lain tidak dapat ditambahkan pasal 18 ayat (2) karena sama sekali tidak ada unsur kerugian negara.

Komulasi antara pidana pokok (penjara) dan pidana pokok lain (denda) yang erat dengan pidana kurungan pengganti ( Pasal 30 ayat 2 KUHP ), serta di dalam Undang - Undang Pemberantasan Tindak Pidana Korupsi juga telah menetapkan batasan tersebut yang menetapkan aturan minimal dan maksimal, sehingga sedemikian jika seorang hakim menjatuhkan pidana bersyarat bagi koruptor tidak dapat dibenarkan, walaupun hakim mempunyai kekuasan dalam menjatuhkan vonis bagi terpidana korupsi.

Adanya batasan minimal dan maksimal sanksi penjara dan denda dalam UUPTPK tidak membatasi kebebasan seorang hakim dalam menjatuhkan pidana terhadap pelaku tindak pidana, karena batasan minimal dalam peraturan perundang - undangan khusunya tindak pidana korupsi tetap memberikan kebebasan kepada hakim yaitu dengan adanya ancaman pidana maksimal, dengan kata lain hakim dapat masih dapat menentukan pidana penjara berdasarkan hal - hal yang meringankan maupun memberatkan perbuatan pidana yang melakukan. 
Andi Hamzah mengatakan " di dalam undang- undang tindak pidana korupsi memang ada syarat minimal, tetapi di dalam undang - undang tersebut juga tidak melarang apabila hakim memutuskan pidana bersyarat terhadap terdakwa korupsi, aturan pidana bersyarat yang diatur dalam pasal 14 KUHP berlaku sebagai undang - undang bersifat umum, oleh karena dalam undang - undang tindak pidana korupsi tidak diatur pidana bersyarat, tetapi karena aturan dalam pasal 14 KUHP tersebut bersifat umum maka aturan tersebut digunakan dalam kasus kasus tertentu yang ancamannya minimal dalam undang - undang adalah 1 tahun bahkan ketua mahkamah agung bagirmanan pernah mengimbau kepada jajaran hukim, agar terhadap kasus kasus yang nilainya dibawah Rp.5000.000.,-' ( lima juta rupiah), kemudian terdakwa tidak menikmati hasil korupsi tersebut dan telah mengembalikan nilai korupsi yang ada, serta dampak dari perbuatan korupsi itu tidak merugikan masyarakat, maka terhadap perkara - perkara semacam itu jangan terlalu menerapkan undang - undang tindak pidana korupsi secara normatif' 14

Sedangkan para ahli hukum pidana sepakat pidana bersyarat memiliki kedudukan yang penting sebagai alternatife pemidaanaan non institusional khususnya untuk menggantikan bentuk pidana badan baik penjara atau kurungan, yang menjadi bentuk paling umum dari suatu pemidanaan, pidana bersyarat dianggap lebih efektif mengurangi kejahatan yang bertujuan memberikan kesempatan pada pelaku tindak pidana untuk memperbaiki dirinya secara non istitusional di dalam masyarakat,

14 https://psod.wordpress.com/mencermati-vonis-percobaan-dalam-tindak-pidanakorupsi/diaksespada tanggal 12 april 2018 
aspek rehabilitas suatu pemidanaan menjadi titik berat dalam bentuk pemidanaan bersyarat.

\section{Analisa Putusan No 675. K/Pid.Sus./2010 Dakwaan dan tuntutan}

terdakwa Cik Umar Agus, SH. Bersama Solahudin Bin Ahmad Najamudin yang diatur dan diancam pidana berdasarkan dakwaan Primair:pasal 12 e Undang- Undang RI No 31 Tahun 1999 TentangPemberantasan Tindak Pidana Korupsi sebagaimana telah diubah dan ditambah UUNo 20 Tahun 2001 Tentang Perubahan atas Undang- Undang No 31 Tahun1999 Tentang Pemberantasan Korupsi Jo pasal 55 ayat (1) ke-2 KUHP yang berbunyi sebagai yang memberi kesempatan, sarana, atau keterangan, sengaja menganjurkan oranglain supaya melakukan perbuatan tindak pidana korupsi, sebagai pegawai negeri, atau penyelenggara negara yang dengan maksud menguntungkan diri sendiri atau orang lain secara melawan hukum, atau dengan menyalah gunakan kekuasannya memaksa seseorang memberikan sesuatu membayar atau menerima bayaran dengan potongan, atau untuk mengerjakan sesuatu bagi dirinya sendiri dan Subsidiar: pasal 11 Undang - Undang RI No 31 Tahun 1999 Tentang Pemberantasan Tindak Pidana Korupsi sebagaimana telah di ubah dan ditambah UndangUndang No 20 Tahun 2001 Tentang Perubahan Atas Undang-Undang No 31 Tahun 1999 Tentang Pemberantasan Tindak Pidana Korupsi, sebagai yang memberikan kesempatan, sarana atau keterangan, sengaja, menganjurkan orang lain supaya melakukan perbuatan tindak pidana korupsi, sebagai pegawai negeri atau penyelenggara negara yang menerima hadiah atau janji padahal diketahui atau patut diduga bahwa hadiah atau janji tersebut diberikan karena kekuasaannya atau kewenangannya yang berhubungan dengan jabatannya atau yang menurut pikiran orang yang memberikan hadiah atau janji tersebut ada hubunganya dengan jabatannya.

Pertimbangan Hakim Menjatuhkan Pidana Bersyarat 
Bahwa majelis hakim pengadilan negeri lahat telah salah dalam menerapkan hukum dimana telah melanggar pasal 11 Undang-Undang No 31 Tahun 1999 Tentang Pemberantasan Tindak Pidana Korupsi Jo Undang-Undang No 20 Tahun 2001Jo pasal 55 ayat (1) ke-2 KUHP, yang mana dalam fakta - fakta persidangan yang melakukan tindak pidana korupsi bukanlah terdakwa Cik Umar Agus tetapi Solahudin, maka dengan itu tidak jelas apakah terdakwa sebagai orang yang melakukan tindak pidana korupsi atau orang yang menganjurkan oranglain melakukan tindak pidana dimana dalam doktrin hukum pidana merupakan suatu perwujudan dalam tindak pidana tersendiri, sehingga dalam penerapan sanksi pidananya mereka dianggap sama sebagai pelaku.

Bahwa pengadilan tinggi Palembang telah salah dalam menerapkan hukum yaitu tidak melaksanakan ketentuan pasal, dimana Pasal 11Undang- Undang No 31 Tahun 1999 ancaman pidananya minimal 1(satu) Tahun dan paling lama 5 (lima) Tahun serta denda paling sedikit Rp 50.000.000,- (lima puluh juta rupiah) dan Paling banyak Rp250.000.000,-(dua ratus lima puluh ribu rupiah), sehingga dengan demikin majelis hakim menjatuhkan pidana 6 bulan penjara dan denda Rp 10.000.000,-(sepuluh juta rupiah) bertentangan dengan kaedah dan norma yang diatur dalam Undang - Undang tersebut yang kurang mencerminkan rasa keadilan

\section{e. Amar putusan}

Dalam hal ini majelis hakim mahkamah agung menjatuhkan kepada terdakwa Cik Umar Agus SH. dengan menjatuhkan pidana kepada terdakwa hanya pidana penjara 1 (satu) Tahun dan pidana denda sebesar Rp 50.0000.000,- (lima puluh juta rupiah) dengan ketentuan apabila pidana denda tidak dibayar, maka kepada terdakwa dikenakan hukuman pengganti berupa pidana kurungan selama 1(satu) Tahun. Serta memerintahkan pidana tersebut tidak perlu dijalani kecuali apabila kemudian hari dalam putusan hakim diberikan perintah lain 
atas alasan terdakwa sebelum masa percobaan selama 2 (dua) Tahun Terakhir telah bersalah melakukan tindak pidana.

\section{KESIMPULAN}

Pertama, pertimbangan hakim dalam menjatuhkan pidana bersyarat adalah majelis hakim pengadilan negeri lahat telah salah dalam menerapkan hukum dimana telah melanggar melanggar pasal 11 Undang-Undang No 31 Tahun 1999 Tentang Pemberantasan Tindak Pidana Korupsi Jo Undang-Undang No 20 Tahun 2001Jo pasal 55 ayat (1) ke-2 KUHP, yang mana dalam fakta - fakta persidangan yang melakukan tindak pidana korupsi bukanlah terdakwa Cik Umar Agus tetapi Solahudin dalam doktrin hukum pidana merupakan suatu perwujudan dalam tindak pidana sendiri, sehingga dalam sanksi pidana mereka dianggap sama sebagai pelaku.

Kedua Pasal 11Undang- Undang No 31 Tahun 1999 ancaman pidananya minimal 1(satu) Tahun dan paling lama 5 (lima) Tahun serta denda paling sedikit Rp 50.000.000,- (lima puluh juta rupiah) dan Paling banyak Rp250.000.000,-(dua ratus lima puluh ribu rupiah), sehingga dengan demikin majelis hakim menjatuhkan pidana 6 bulan penjara dan denda Rp 10.000.000,(sepuluh juta rupiah) bertentangan dengan kaedah dan norma yang diatur dalam Undang - Undang tersebut yang kurang mencerminkan rasa keadilan.

\section{SARAN}

Pertama Bahwa berdasarkan pasal 179 ayat (1) huruf C KUHAP, dakwaan, sebagiamana terdapat dalam surat dakwaan yang mana majelis Hakim agung mengkaji apabila suatu putusan yang didasarkan pada pasal yang tidak di dakwakan makan 
putusan tersebut di anggap batal demi hukum .sebagaimanaPutusan Mahkamah Agung RI No; 402K/Pid./1987.

Kedua karena putusan Mahkamah Agung sebagai yurisprudensi ada baiknya terhadap kasus tipikor jangan di berikan hukuman pidana bersayarat karena bertentangan dengan sanski pidana minimum dalam undang - undang pemberantasan korupsi yang dapat menimbulkan efek jera .

\section{DAFTAR PUSTAKA}

\section{BUKU}

Alfitra,Modus Operandi Pidana Khusus Diluar KUHP,Jakarta:RaihAsas Sukses,2014

Gugur Atau Batalnya Hak Penuntutan Serta Menjalankan Pidana Menurut Hukum Positif Indonesia, Sejahtera Printing, Jakarta, 2010

Barda Nawawi Arief, Bunga Rampai Kebijakan Hukum Pidana, Citra Aditya Bakti, Bandung, 2002

E.Y.Kanter, Asas ${ }^{-}$Asas Hukum Pidana Di Indonesia Dan Penerapannya,Jakarta : Storia Grafika, 2012.

Kamus Hukum, Fockema Andrea, Bandung : Bina Cipta,1983 . Huruf C Terjemahan Bina Cipta

Lilik Mulyadi, Pembalikan Beban Tindak Pidana Korupsi, Penerbit PT . Alumni , Cetakan Ke - 1 Tahun 2007

Oemar Seno Adji, Peradilan Bebas Negara Hukum, Erlangga ,Jakarta 1987

Roeslan Saleh, Mengadili Sebagai Pergulatan Kemanusiaan, Aksara Baru, Jakarta, 1979

Juhaya S Praja ,Teori Hukum Dan Aplikasinya, Bandung : Pustaka Setia, Cetakan Kedua 2014

Perundang - Perundangan:

Kitab Undang - Undang Hukum Pidana ( KUHP)

Undang - Undang No 31 Tahun 1999 Tentang Pemberantasan Tindak Pidana Korupsi 
Undang- Undang No 20 Tahun 2001 Tentang Perubahan Atas Udang - Undang No 31 Tahun 1999 Tentang Pemberantasan Tindak Pidana Korupsi

Undang - Undang No 30 Tahun 2002 Tentang Komisi Pem,Berantasan Korupsi

Undang - Undang No 48 Tahun 2009 Tentang Kekuasaan Kehakiman

\section{INTERNET :}

https://psod.wordpress.com/mencermati-vonis-percobaan-dalamtindak-pidana-korupsi/diaksespada tanggal 12 april 2018 

